\title{
Pareto Analysis of Critical Success Factors for Total Quality Management Targeting the Service Industry
}

\author{
Tahira Mahboob \\ Assistant Professor, \\ Software Engineering, \\ Fatima Jinnah Women \\ University, Pakistan
}

\author{
Bushra Tariq \\ Department of Software \\ Engineering, Fatima \\ Jinnah Women \\ University, Pakistan
}

\author{
Seemi Anwar \\ Department of Software \\ Engineering, \\ Fatima Jinnah Women \\ University, Pakistan
}

\author{
Mamoona Khanum \\ Assistant Professor, \\ Computer Science, \\ Fatima Jinnah Women \\ University, Pakistan
}

\begin{abstract}
Quality is an important aspect of software development. This is the reason some researchers and practitioners have attempted to integrate TQM concepts into software engineering. Total Data Quality Management (TDQM) methodology claims that we should manage data as we manage products, but principles, guidelines, and techniques of Total Quality Management for physical products have limitations in TDQM practices because of the nature of data. In our research we have studied about 22 research papers in which different strategies, issues of TQM challenges and how to overcome these challenges are discussed.
\end{abstract}

\section{Keywords}

Total quality management (TQM); critical success factors (CSF); service industries; Pareto analysis; service industries, continuous improvement.

\section{INTRODUCTION}

Total Quality Management, TQM is a procedure through which for the continuous improvement of the manufacture of things, management and employees can tangle. TQM is a combination of management and quality tools the main purpose of using them is to increase business and reduce losses due to inefficient practices. The codes of TQM are described in the given paper which is Employee Authorization, Organization Assurance, Customer Emphasis and Continuous Improvement. In accomplishing business success, Quality reproduced a planned factor. By taking a view at all the contributions; the study collected a TQM model comprising following 11 measurements: leadership and top management commitment, employee involvement, employee empowerment, education and training, teamwork, customer focus, process management, strategic planning, open organization, information and analysis system, and service [1]. TQM is a viewing platform generally exposed by large companies. A general view is that when new managerial viewpoints and new advanced technologies are presented and implemented, small businesses always lag behind larger ones. Most of the small firms have stopped at quality system Certification, such as ISO 9000, in their quality journey instead of following advance improvement hard work through TQM [2]. It is pretended that a small TQM trade can comprise of a wide range of quality enterprises but not surely to the same balance as in large TQM industries. The identical balance like large TQM businesses can be achieved by understanding and having the essential knowledge of TQM. In implementing TQM, a small company can be successful because of the reason that it knows the necessity to continuously development in every phase of its business.

In the early years of the computer industry, hardware was the major cost component of any information system. However, software has gradually become the lager part of the cost equation. Total quality management recently has its potential been realized in the arena of software development. There are three main concepts which use to illustrate the relevance and the importance of TQM in software engineering i.e Quality evolution, Quality dimensions and Quality management. Furthermore, it can be noticed the great contribution for an organization to integrate the Quality Management and implement it as a whole with the commitment of everybody involved. In the eighties, we observed the beginning of the TQM - Total Quality Management whose focus was on the customer and market needs. All these quality concepts evolution had been developed and demonstrated successfully by the effort and work of important quality specialists.

The total quality management (TQM) concept represents a fundamental change in the definition and treatment of quality in product development. Under the TQM concept, quality is defined and judged by the customer. Therefore, it acknowledges a customer-driven economy. It focuses on continuous process improvement to achieve high quality of product (or service). Its strategy tries to achieve "total quality" throughout the entire business, not just in the product. Productivity gains can be achieved through quality improvements. To increase the chance of success, a TQM implementation project should start from the top management and unfold it downward to lower-level management and workers with a goal to benefit the critical mass of employees. Total Data Quality Management (TDQM) methodology claims that we should manage data as we manage products, but principles, guidelines, and techniques of Total Quality Management for physical products have limitations in TDQM practices because of the nature of data. Data's lifecycle process is divided into three phases, design, manufacturing and application. Based on the model, quality problems are resolved in the phase which they arise initially and avoided complication in the next operation.

\section{LITERATURE REVIEW}

Dinh Thai Hoanga , Barbara Igelb and Tritos Laosirihongthong proposed a relative study on the relationship among implementation of total quality management (TQM) and organizational characteristics in a recently developed country in South East Asia. Quality reflected a planned factor in accomplishing business success. 
It states that quality is more than ever required for challenging successfully in today's global market place. The main purpose for taking Vietnam as a case study is that this country has become the 150th member of the World Trade Organization (WTO), a landmark predictable to launch an era of fundamental changes as the socialist nation enters the global market place. The relationship between TQM and structural features many previous studies expose that the size of a company and principal ownership are related to management practices in implementation of TQM. For example, organizational culture references to attitudes, beliefs, and conditional relations. It has been influenced by various types of ownership. As a result, the mark of TQM use is different [1].Small firms have embarked on TQM for different reasons. Sha'ri M. Yusof and Elaine Aspinwall provided an understanding of implementation of TQM in a small business. In this paper many researchers address several topics related to Total Quality management and proposed Continuous improvements. Early studies on quality initiatives in small businesses have largely focused on achieving product quality and on the application of statistical techniques. Major reasons for implementing TQM have been described in the given paper. Small firms have embarked on TQM for different reasons. Hashmi Khurram describes the central principle of TQM that is mistakes and errors may be made by people, but most of them are caused, by faulty apparatus and processes. Therefore, cause of such mistakes can be recognized and eliminated, and can be prevented in future by changing the process. Therese A. Joiner discovers the relationship between the scope of TQM application and business performance, and the controlling effect of co-worker support and business support on the TQM vs. performance relationship. There is growing credit of the importance of human aspects in quality management within the perspective of popular TQM implementation. Major features of TQM comprises of teamwork, administration, communication between customers and organization, customer feedback, employee participation and authorization, employee and management trust and support. This study focused on the Sample and data collection for example motor vehicle parts and accessories trade firms in Australia. This collection was made because there is indication that the automotive industry of Australia has comprised the role of quality in its improvements. Second part which is described in paper is variables and measures TQM. Ola Ibrahim (2013) proposed a comparative analysis of some of the researcher's approaches towards Total quality Management Models, Applications, philosophies and goals[3].Human resources are equally important for TQM success. Therefore, it could be said that people's awareness of quality is central to TQM's purpose. In this respect, the major argument of the article is that although the acronym of TQM and some of its concepts and practices are known by our interviewees, actual awareness of its "soft" side is often superficial and people have a relatively poor understanding of it. Managers tend to see TQM from a technical point of view, being aware only of the importance of its "hard" aspects. Renato L. Della Volpe, Farley S.M. Nobre proposed a paper which experiences of how to structure and to apply SQM in an environment of TQM and the contribution benefits and results achieved. Furthermore, it can be noticed the great contribution for an organization to integrate the Quality Management and implement it as a whole with the commitment of everybody involved [10]. Mitchell K. D. Ram, proposed that there are three main concepts to illustrate the relevance and importance of TQM to software engineering: Quality evolution, Quality dimensions and Quality management.
A major component of TQM is the people involved. In the software engineering context, this component includes the end-users and the software developers. These developers are the implementers of the TQM and software engineering integration. It is important that they are trained not only to produce quality software, but also to manage the software development process, with the focus on total quality.[9]Colson, Joseph S.Prell, Edward M., in their paper focuses on the challenges faced by $5 \mathrm{ESS}$ and how total quality management overcomes these challenges. 5ESS is 5 class telephone electronic switch system which was designed and developed byAT\&T as a universal digital exchange to meet the needs of telecommunication administrations making the transition from analog to digital exchanges. As The TQM highlights that, how to simultaneously improve quality, shorten the interval between product development and delivery, reduce costs, and increase revenues. This paper summarizes the approach, current status, and some early results of our efforts to conceptualize, design, and achieve a quality management system for the international and U. S. 5ESS switch projects. Conceptually, TQM is an integrated management approach designed to transform customer needs and requirements into customer satisfaction and business success.[11]

Thomas J. Bradley, identified that Total Quality Management (TQM) focus is a strategic requirement in the highly competitive telecommunications industry. This paper describes how significant progress towards TQM can be achieved in software development lifecycle via the implementation of a comprehensive defect prevention program. The results of the initiative $m$ increased productivity, high product quality, and better customer satisfaction. Many approaches and methodologies can be used in establishing the cultural framework for TQM such as, ACHIEVING TQM VIA DEFECT PREVENTION. It is a basic model of a defect prevention process applicable to any stage of software development lifecycle was described in the literature from IBM. This process consists of four key activities which are integrated into the development stage. These activities are Causal analysis meetings, an action team, a stage kick-off meeting, and data collection and tracking system.[12]

Sinclajr Stockman, In their research paper experienced that software development organization which has moved over the past few years from the straightforward IS09001 process control approach, to the more dynamic continuous improvement model. Customer satisfaction surveys, performed independently, face to face with the customer, aimed at identifying both strengths and weaknesses, and taking action to address any issues identified. This paper has covered briefly the author's experiences with TQM as a result of its introduction into a software development organization which had a long history of the use of IS09001 Quality Systems.[13]

Eldon Y. Li, Houn-Gee Chen, Waiman Cheung, proposed that the total quality management (TQM) concept represents a fundamental change in the definition and treatment of quality in product development. Under the TQM concept, quality is defined and judged by the customer. Therefore, it acknowledges a customer-driven economy. It focuses on continuous process improvement to achieve high quality of product (or service). Its strategy tries to achieve "total quality" throughout the entire business, not just in the product. Any software organization that is planning to implement the TQM must have the critical mass of its employees embrace the 
TQM philosophy and methods before jumping onto the bandwagon. That is, all employees regardless of their ranks must fully understand (or be trained with) and internalize the TQM concept and tools. To increase the chance of success, a TQM implementation project should start from the top management and unfold it downward to lower-level management and workers with a goal to benefit the critical mass of employees.[14]

Jianjun Cao, Xingchun Diao, Guoquan Jiang, proposed that "Total Data Quality Management", (TDQM)methodology claims that we should manage data as we manage products, but principles, guidelines, and techniques of Total Quality Management for physical products have limitations in TDQM practices because of the nature of data. Data's lifecycle process is divided into three phases, design, manufacturing and application. Based on the model, quality problems are resolved in the phase which they arise initially and avoided complication in the next operation.. TDQM is one of high expensive engineering. However, data analysts hope that data management doesn't influence their work. Author has proposed some innovative viewpoints for improving data quality conforming to TDQM.

\section{ANALYSIS}

In our study we studied 22 papers and from the scope of theses 22 papers we extracted critical success factors of TQM that are vital few. At first, we apply a Pareto analysis quality tool and sort the critical success factors in descending order according to the frequencies of their occurrences and then explore and propose a final list of "vital few" CSFs of TQM which could benefit the researchers and services industries. From our work we analyze that Pareto chart shows that $80 \%$ of the complaints come from $20 \%$ of the complaint types (Quality system and performance QSP).

\section{CONCLUSION}

The paper concluded that top-management commitment is listed as the top CSFs with customer focus and satisfaction close behind. In this paper we use the Pareto analysis to analyze the total quality management be can also use many other tools and techniques to analyze TQM for example vector comparative analysis.

It also examined the work of leading authors to ascertain the "vital few" and "useful many" CSFs for successful implementation of TQM program in service industries for effective business performance and improvements in quality service. Managers can use a set of "vital few" CSFs in their organization and link them with both operational and organizational performance. The results of the present study will help managers and practitioners in smoother implementation of TQM program in service industries.

\section{REFERENCES}

[1] Dinh Thai Hoanga , Barbara Igelb and Tritos Laosirihongthong (September 2010). Total quality management (TQM) strategy and organizational characteristics: Evidence from a recent WTO member Vol. 21.

[2] Sha'ri M. Yusof and Elaine Aspinwall (2006). TQM implementation issues: review and case study. Available [online] http://www.emeraldinsight.com/doi/abs/10.1108 /01443570010321595

[3] Ola Ibrahim International Journal of Scientific and Research Publications, Volume 3, Issue 10, October 20131 ISSN 2250-3153. Total Quality management
(TQM) and Continuous Improvement as Addressed by Researchers. Available [online] http://www.ijsrp.org/ research-paper 1013/ijsrp-p2279.pdf

[4] Therese A. Joiner. Total quality management and performance The role of organization support and coworker support. January 2006. Available[online] http://www.emeraldinsight.com/doi/abs/10.1108/026567 10710757808

[5] Hashmi, Khurram. "Introduction and Implementation of Total Quality Management." iSix Sigma (2010). Available [online] http://www.isixsigma.com/ methodology/total-quality-managementtqm/introduction-and-implementation-total-qualitymanagement-tqm/

[6] Alexandros G. Psychogios City College, ConstantinosVasilios Priporas (March 2007).Understanding Total Quality Management in Context: Qualitative Research on Managers' Awareness of TQM Aspects in the Greek Service Industry Volume 12. Available [online] http://www.nova.edu/ssss/QR/QR12-1/psychogios.pdf

[7] Takehisa Kajiwara(December 2009). Factors influencing the use of quality costs in TQM environments: Evidence from Japan. Available[online] http://papers.ssrn.com/ sol3/papers.cfm?abstract_id=1444763

[8] Senda WALI (October 13-14, 2007) Factors affecting TQM implementation: an empirical study in Tunisian firms. Available [online] www.gcbe.us/7th_GCBE/data/Senda\%20Wali.doc

[9] Mitchell K. D. Ram, "Total Quality Management in Software Engineering", Department of Management Science and Information Systems, University of Auckland. Published in: Software Education Conference, 1994.Proceedings.IEEE conference publication.

[10] Renato L. Della Volpe, Farley S.M. Nobre "The Role of Software Process Improvement into Total Quality Management: An Industrial Experience", Published in: Engineering Management Society, 2000. Proceedings of the 2000 IEEE, IEEE conference publication.

[11] Colson, Joseph S.Prell, Edward M., "Total Quality Management for a Large Software Project". Published in: AT\&T Technical Journal (Volume:71, Issue: 3 ) 2014, IEEE conference publication.

[12] Thomas J. Bradley, "The Use of Defect Prevention in achieving Total Quality Management in the Software Life Cycle", Published in: Communications, 1991. ICC '91, Conference Record. IEEE

[13] Sinclajr Stockman, "Total Quality Management in Software Development" Published in:Global Telecommunications Conference, 1993, including a Communications Theory Mini-Conference. Technical Program Conference Record, IEEE in Houston. GLOBECOM '93., IEEE conference publication

[14] Eldon Y. Li, Houn-Gee Chen, Waiman Cheung, "Total Quality Management in Software Development Process", The Journal of Quality Assurance Institute, Vol. 14, No.1, January $2000 . \quad$ Online: http://www.cob.calpoly.edu/ eli/pdf/jqai-00.pdf

[15] Jianjun Cao, Xingchun Diao, Guoquan Jiang, "Data Lifecycle Process Model and Quality Improving Framework for TDQM Practices", 2010 Published in:E- 
Product E-Service and E-Entertainment (ICEEE), 2010 International Conference on, , IEEE conference publication

[16] Kan, S.H., "Software quality: An overview from the perspective of total quality management"6 April 2010, IBM Systems Journal (Volume: 33, Issue: 1 ). Publisher: IBM

[17] Thompson, D. "Systems engineering applied to total quality management", Published in: Successful Introduction of Systems Engineering into an Organisation (Ref. No. 1999/037), IEE Colloquium on

[18] Bradley, T.J. ; Northern Telecom Inc., Research Triangle Park, "The use of defect prevention in achieving total quality management in the software life cycle". Published in: Communications, 1991. ICC '91, Conference Record. IEEE

[19] Rosiczkowski, J.W.; Alfred Univ., NY, USA ; Hahn, W.F., "Total quality management and engineering education at Alfred University", Published in: Frontiers in Education Conference, 1993. Twenty-Third Annual
Conference. 'Engineering Education: Renewing America's Technology', Proceedings.

[20] Raven, M.E, Wixon, D.“Total Quality Management Using Vector comparative Analysis". Published in:IPCC 92 Santa Fe. Crossing Frontiers. Conference Record, Publisher: IEEE

[21] Faisal Talib, Zillur Rahman, M.N. Qureshi "Pareto analysis of total quality management factors critical to success for service industries". Available [online] http://www.ijqr.net/journal/v4-n2/8.pdf

[22] Maria Leticia Santos-Vijande "TQM and firms performance: An EFQM excellence model research based survey". Available. [online] http://business-andmanagement.org/library/2007/2_2--21-41,SantosVijande,Alvarez-Gonzalez.pdf

\section{APPENDIX}

Table 1: Analysis of Critical Success Factors in TQM

\begin{tabular}{|c|c|c|c|}
\hline Sr & Authors & $\begin{array}{l}\# \text { of } \\
\text { CSFs }\end{array}$ & TQM CSFs \\
\hline 1 & $\begin{array}{l}\text { Dinh Thai Hoanga, } \\
\text { Barbara Igelb and Tritos } \\
\text { Laosirihongthong }\end{array}$ & 11 & $\begin{array}{l}\text { Leadership/top management commitment, employee involvement, employee } \\
\text { empowerment, education \& training, teamwork, customer focus, process management, } \\
\text { strategic planning, open organization, information and analysis system, and service }\end{array}$ \\
\hline 2 & $\begin{array}{l}\text { Sha'riM.Yusof, Elaine } \\
\text { Aspinwall }\end{array}$ & 2 & Product quality, application of statistical techniques. \\
\hline 3 & Ola Ibrahim & 6 & $\begin{array}{l}\text { Total quality Management Models, Applications, philosophies and goals, Total Quality } \\
\text { Management (TQM) Framework for e-learning, (TQM) Principles. }\end{array}$ \\
\hline 4 & Therese A. Joiner & 10 & $\begin{array}{l}\text { Relationship b/w scope of TQM application \& business performance, controlling effect } \\
\text { of co-worker/ business support, TQMVsperformance relationship, Quality management } \\
\text { teamwork, administration, communication b/w customers \& organization, customer } \\
\text { feedback, employee participation \& authorization, employee/management trust/support. }\end{array}$ \\
\hline 5 & Hashmi, Khurram & 4 & $\begin{array}{l}\text { Organization Assurance, Employee Authorization, Continuous Improvement, and } \\
\text { Customer Emphasis }\end{array}$ \\
\hline 6 & AlexandrosG. sychogios & 3 & Quality principles and techniques, Human resources, managers' attitudes towards TQM \\
\hline 7 & TakehisaKajiwara & 3 & $\begin{array}{l}\text { Quality cost in TQM, quality management literature, nonfinancial performance } \\
\text { measures, such as defect rates, cycle time, and customer satisfaction, }\end{array}$ \\
\hline 8 & Senda WALI & 2 & Total Quality Control (TQC), quality circles \\
\hline 9 & Mitchell K. D. Ram & 8 & $\begin{array}{l}\text { Quality evolution, quality management, quality dimensions, performance, } \\
\text { relaiability, serviceability.Conformance and durability. }\end{array}$ \\
\hline 10 & $\begin{array}{l}\text { Renato L. Della Volpe, } \\
\text { Farley S.M. Nobre }\end{array}$ & 10 & $\begin{array}{l}\text { Direction and goal establishment, Management framework, communication, skill and } \\
\text { knowledge, software quality, corrective action, quality record, Management } \\
\text { responsibility, Quality system and training. }\end{array}$ \\
\hline 11 & $\begin{array}{l}\text { Colson, Joseph S.Prell, } \\
\text { Edward M. }\end{array}$ & 6 & $\begin{array}{l}\text { Reduce cost, increase revenues, strategic quality planning, continuous process } \\
\text { improvement, process decomposition and process management team. }\end{array}$ \\
\hline 12 & Thomas J. Bradley & 5 & $\begin{array}{l}\text { Strategic requirement, defect prevention, better quality and customer satisfaction and } \\
\text { quality improvement project teams. }\end{array}$ \\
\hline 13 & Sinclajr Stockman & 5 & $\begin{array}{l}\text { Quality management, project management, configuration management, control process } \\
\text { and quality management system. }\end{array}$ \\
\hline 14 & $\begin{array}{l}\text { Eldon Y. Li, Houn-Gee } \\
\text { Chen, Waiman Cheung, }\end{array}$ & 3 & Product development, productivity gain, process improvement and high quality product. \\
\hline 15 & $\begin{array}{l}\text { Jianjun Cao, } \\
\text { XingchunDiao, Guoquan }\end{array}$ & 6 & $\begin{array}{l}\text { Data Quality, Total Data Quality Management, Life cycle Process Model, } \\
\text { Data Cleaning, Integrity Constraints, Data Integration }\end{array}$ \\
\hline 16 & Kan, S.H & 3 & Quality management, process improvement, Data Cleaning \\
\hline 17 & Thompson, D & 4 & $\begin{array}{l}\text { Process management team, customer satisfaction, Management responsibility, skill and } \\
\text { knowledge }\end{array}$ \\
\hline 18 & Bradley, T.J. & 5 & $\begin{array}{l}\text { Employee involvement, customer focus, process management, education and training, } \\
\text { teamwork. }\end{array}$ \\
\hline 19 & Rosiczkowski, J.W & 3 & Product quality, application of statistical techniques. \\
\hline
\end{tabular}




\begin{tabular}{|c|lr|l|l|}
\hline 20 & \multicolumn{2}{|l|}{ Raven, M.E, Wixon, D. } & 2 & Quality principles, Human resources \\
\hline 21 & $\begin{array}{l}\text { Faisal } \\
\text { ZillurRahman, Malib, } \\
\text { Qureshi }\end{array}$ & 12 & $\begin{array}{l}\text { Organization Assurance, Quality Techniques, customer focus, process management, } \\
\text { strategic planning, open organization, information and analysis system and service } \\
\text { employee involvement, employee empowerment, education and training, teamwork. }\end{array}$ \\
\hline 22 & $\begin{array}{l}\text { Maria Leticia Santos- } \\
\text { Vijande }\end{array}$ & 5 & $\begin{array}{l}\text { Strategic planning, education and training, Human resources, Integrity Constraints, } \\
\text { Data Integration. }\end{array}$ \\
\hline
\end{tabular}

Table 2: List of CSFs-vital few

\begin{tabular}{|c|c|c|c|c|c|}
\hline Critical SuccesFactors & Symbols & Frequency of occurences & Percentage frequency of occurrences & Cumulative Count & Cumulative Percentage \\
\hline $\begin{array}{l}\text { Quality systems and } \\
\text { Performance }\end{array}$ & QSP & 19 & 11.94968553 & 19 & 12 \\
\hline $\begin{array}{l}\text { Top management } \\
\text { commitment }\end{array}$ & TQC & 17 & 10.6918239 & 36 & 23 \\
\hline Training and Education & TE & 16 & 10.06289308 & 52 & 33 \\
\hline $\begin{array}{l}\text { Continuous Improvement } \\
\text { and Customer Emphasis }\end{array}$ & $\mathrm{CIM}$ & 16 & 10.06289308 & 68 & 43 \\
\hline $\begin{array}{l}\text { Customer focus and } \\
\text { satisfaction }\end{array}$ & CFS & 14 & 8.805031447 & 82 & 52 \\
\hline $\begin{array}{l}\text { Quality information and } \\
\text { performance measurement }\end{array}$ & QIPM & 13 & 8.176100629 & 95 & 60 \\
\hline Supplier management & SM & 12 & 7.547169811 & 107 & 67 \\
\hline Employee Authorization & EA & 10 & 6.289308176 & 117 & 74 \\
\hline Communication & COM & 9 & 5.660377358 & 126 & 79 \\
\hline Process management & PM & 8 & 5.031446541 & 134 & 84 \\
\hline $\begin{array}{ll}\text { Human } & \text { resource } \\
\text { management } & \end{array}$ & HRM & 7 & 4.402515723 & 141 & 89 \\
\hline Quality Assurance & QA & 6 & 3.773584906 & 147 & 92 \\
\hline Product Quality & $P Q$ & 5 & 3.144654088 & 152 & 96 \\
\hline $\begin{array}{l}\text { Total Data Quality } \\
\text { Management }\end{array}$ & TDQM & 4 & 2.51572327 & 156 & 98 \\
\hline $\begin{array}{l}\text { Strategic } \\
\text { management }\end{array}$ & SQM & 3 & 1.886792453 & 159 & 100 \\
\hline & & 159 & 100 & & \\
\hline
\end{tabular}



" strategic quality management

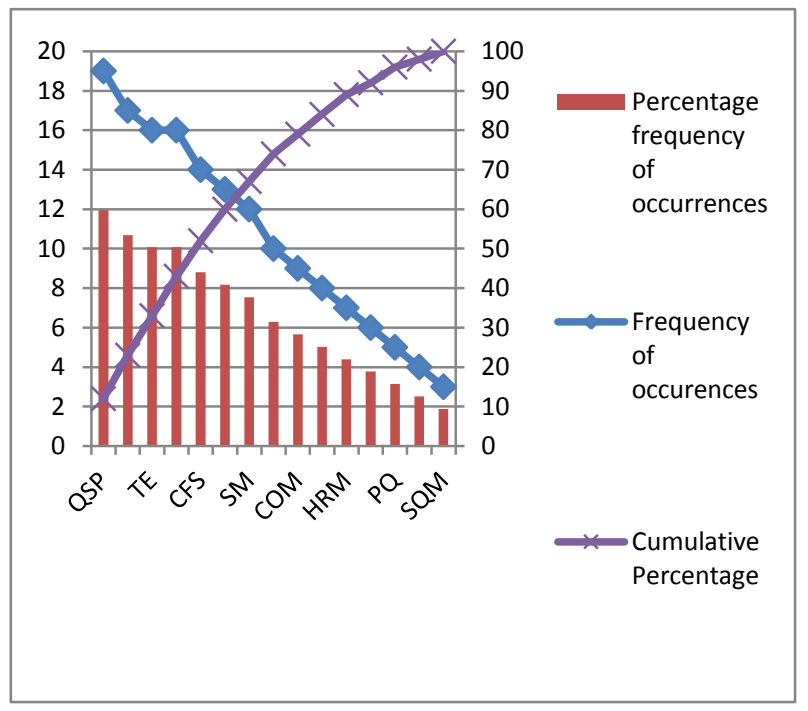

Figure 1: Pareto analysis of TQM CSFs

Figure 2: Pie Chart of TQM CSFs 